University of Nebraska - Lincoln

DigitalCommons@University of Nebraska - Lincoln

2015

\title{
Synthesis of a 2,4,6,8,10-dodecapentanoic acid thioester as a substrate for biosynthesis of heat stable antifungal factor (HSAF)
}

\author{
Andrew S. Olson \\ University of Nebraska-Lincoln \\ Haotong Chen \\ University of Nebraska-Lincoln \\ Liangcheng Du \\ University of Nebraska-Lincoln, Idu3@unl.edu \\ Patrick Dussault \\ University of Nebraska-Lincoln, pdussault1@unl.edu
}

Follow this and additional works at: https://digitalcommons.unl.edu/chemistrydussault

Olson, Andrew S.; Chen, Haotong; Du, Liangcheng; and Dussault, Patrick, "Synthesis of a 2,4,6,8,10-dodecapentanoic acid thioester as a substrate for biosynthesis of heat stable antifungal factor (HSAF)" (2015). Patrick Dussault Publications. 33.

https://digitalcommons.unl.edu/chemistrydussault/33

This Article is brought to you for free and open access by the Published Research - Department of Chemistry at DigitalCommons@University of Nebraska - Lincoln. It has been accepted for inclusion in Patrick Dussault Publications by an authorized administrator of DigitalCommons@University of Nebraska - Lincoln. 


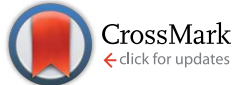

Cite this: RSC Adv., 2015, 5, 11644

Received 18th November 2014 Accepted 9th January 2015

DOI: $10.1039 / c 4 r a 14829 k$

www.rsc.org/advances

\section{Synthesis of a 2,4,6,8,10-dodecapentanoic acid thioester as a substrate for biosynthesis of heat stable antifungal factor (HSAF) $\dagger$}

\author{
Andrew S. Olson, Haotong Chen, Liangcheng Du and Patrick H. Dussault* \\ The $\mathrm{N}$-acetylcystamine (SNAC) thioester of dodecapentaenoic acid, an analog of a putative intermediate in \\ the biosynthesis of Heat Stable Antifungal Factor (HSAF), is synthesized. Key steps include sequential \\ Horner-Emmons homologations with the Weinreb amide of diethylphosponoacetic acid, and \\ thioesterification of an aldol-derived 3-hydroxyalkanoate, which serves as a stable precursor of the \\ sensitive polyenoate. The thioester was investigated as a biosynthetic substrate using a purified \\ nonribosomal peptide synthetase and was not incorporated in the observed products.
}

\section{Introduction}

Heat stable antifungal factor (HSAF, Fig. 1) is a polycyclic tetramate macrolactam produced by the bacterium Lysobacter enzymogenes, a biocontrol agent used for crop protection. ${ }^{1}$ Also known as dihydromaltophilin, HSAF inhibits growth of a wide range of fungal species by disrupting sphingolipid production. HSAF biosynthesis is believed to involve a novel process in which a single-module polyketide synthase/nonribosomal peptide synthetase (PKS-NRPS) assembles two polyketide precursors and an ornithine fragment into the natural products via a sequence which includes cyclization or cycloaddition reactions. ${ }^{1}$

In the course of investigations into the biosynthesis of HSAF, ${ }^{1}$ we required a pentaenoate precursor with which to

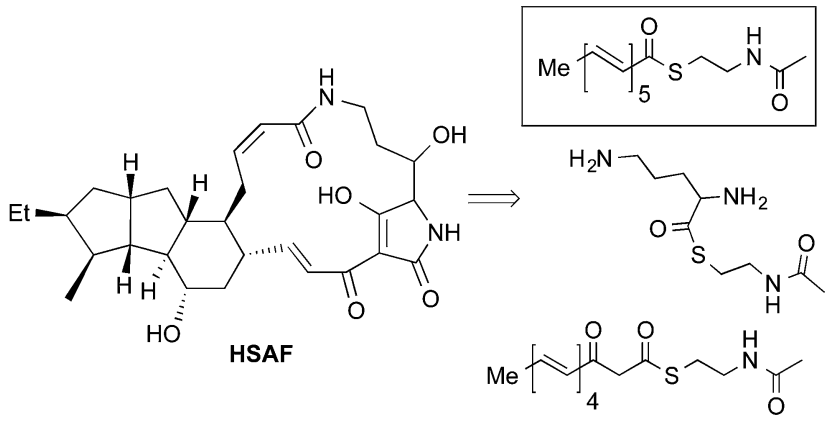

Fig. 1 HSAF and proposed precursors. The boxed molecule is the subject of this paper.

Department of Chemistry, University of Nebraska-Lincoln, Lincoln, NE 68588-0304, USA. E-mail: pdussault1@unl.edu

$\dagger$ Electronic supplementary information (ESI) available. See DOI: $10.1039 / \mathrm{c} 4 \mathrm{ra} 14829 \mathrm{k}$ interrogate the PKS-NRPS synthetase. We now report the synthesis of the $N$-acetyl cystamine thioester (SNAC) of all- $E$ 2,4,6,8,10-dodecapentaenoic acid and our initial findings regarding incorporation into biosynthetic pathways.

Our synthetic approach focused on two major challenges: the need to introduce a thioester in the presence of a highly reactive polyenoate and the desire to be able readily adapt the synthesis to create lengthened or shortened analogs. Many syntheses of polyenes have been reported but few have been applied to unbranched structures and fewer still to the syntheses of thioesters. ${ }^{2-7}$ Although Pd-catalyzed $\mathrm{sp}^{2}-\mathrm{sp}^{2}$ couplings have been applied to convergent ${ }^{8-10}$ and linear construction of polyenes ${ }^{\mathbf{1 1}}$ we were attracted by the simplicity of Horner-Wadsworth-Emmons (HWE) reactions, ${ }^{2,4,12}$ which have been applied iteratively to introduce up to six units of unsaturation. ${ }^{13}$ However, regardless of the method employed for elaboration of the skeleton, the reactivity of the pentaenoate would appear to preclude esterification with a thiol. ${ }^{14}$ As a result, we elected to employ a route in which a 3-hydroxydodecatetraenoate thioester, derived through a combination of Horner-Emmons and aldol reactions, would serve as the precursor of the targeted pentaenoate.

\section{Results and discussion}

Scheme 1 illustrates our synthesis of the pentaenoate thioester (9). We were initially attracted by a report describing synthesis of polyenoates through iterative use of Horner-Emmons homologations. However, in our hands, selective reduction of the polyunsaturated esters proved challenging. ${ }^{5}$ We therefore turned to an approach employing the Weinreb amide of diethylphosphonoacetic acid (2). ${ }^{15}$ Homologation of sorbaldehyde (1) with (2) furnished the trienoate amide (3) in excellent yield. The Horner-Emmons reaction employed $n$-BuLi for convenience; this reaction could also have been conducted with a more easily 

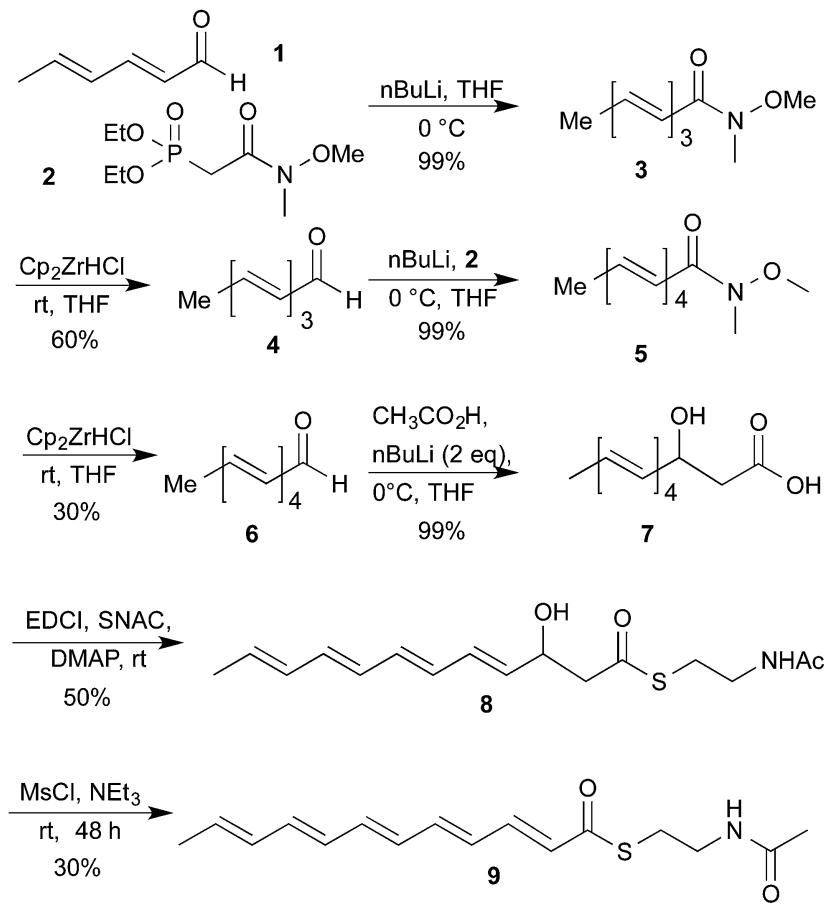

Scheme 1 Synthesis of dodecapentenoate thioester 9.

handled base such as LDA. In contrast to the problems experienced during attempted reduction of the trienoate $O$-esters, reduction of the Weinreb amide with Schwartz's reagent was accomplished in moderate yield but high selectivity ${ }^{16}$ to furnish a dark red and moderately light-sensitive trienal (4). An iteration of the homologation and reduction sequence furnished tetraenal 6. The tetraenal, and all other intermediates and products possessing four or five conjugated alkenes, proved remarkably light sensitive, and all reactions, purifications, and product manipulation were conducted in a darkened room under red light.

We had initially planned to introduce the pentaenoate thioester through a final Horner-Emmons homologation of tetraenal 6 with the SNAC thioester of diethylphosphonoacetic acid. However, this reagent failed to homologate even simple aldehydes (not shown).

An alternate strategy based upon homologation with an unsaturated Horner-Emmons reagent was frustrated by the inability to prepare the necessary thioester due to incompatibility of the enoate and the thiol (Scheme 2).

We therefore chose to perform thioesterification on a masked version of the fully conjugated pentaenoate. Aldol reaction of aldehyde (6) with the dianion of acetic acid generated 3-hydroxy acid (7) in 99\% yield. The hydroxy acid displayed minimal solubility in most organic solvents other than THF and

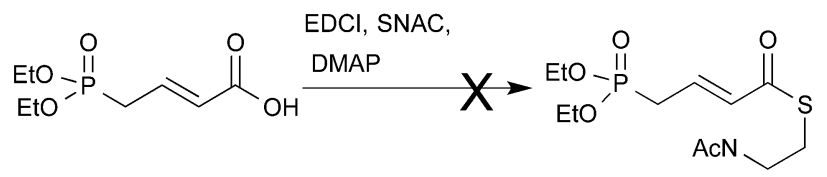

Scheme 2 Failure to prepare thioester of unsaturated phosphonate. interacted so strongly with silica gel that it could not easily be recovered. Fortunately, the aldol reaction generated 7 in sufficiently pure form as to render purification unnecessary. EDCIpromoted reaction of 7 with SNAC selectively generated the desired 3-hydroxyalkanoate thioester (8) in moderate yield. The thioester, like the hydroxyacid, had moderate solubility in solvents other than THF and was retained strongly on silica gel. As a result, separation from byproducts was challenging.

The final step, dehydration of the 3-hydroxyalkanoate thioester, was accomplished in moderate yield using methanesulfonyl chloride and triethylamine. The long reaction time (days) was due to slow conversion to the methanesulfonate. This intermediate was never observed (TLC) and the disappearance of the starting alcohol paralleled formation of the pentaenoate thioester $\mathbf{9}$, a dark $\left(\lambda_{\max }=380 \mathrm{~nm}\right)$ and extremely light-sensitive oil that that undergoes degradation in seconds to minutes upon exposure to indoor fluorescent lights. The pentaenoate is more organic-soluble than the hydroxy acid or hydroxyl ester precursors, and, while still difficult to purify, could be isolated as a single fraction upon column chromatography in the dark. Although the purified material provided HRMS, UV, and ${ }^{13} \mathrm{C}$ data consistent with the target structure, the ${ }^{1} \mathrm{H}$ NMR spectra displayed significant peak broadening. This phenomenon is clearly related to the presence of the thioester, as the corresponding ethyl ester, prepared by a parallel route (not shown), gave narrow and well-defined ${ }^{1} \mathrm{H}$ NMR signals. The line broadening associated with 9 was not improved by deoxygenation of NMR solvents, nor by pretreatment with reagents for oxidation or absorption of thiols. ${ }^{17,18}$ The possibility that the peak broadening was due to small quantities of a delocalized polyene-derived radical, was investigated using the spin traps TEMPO, DMPO, or DEPMO, but we found no sign of a trapped radical. ${ }^{19,20}$

\section{Initial results with biosynthesis}

The hypothesized role of the pentaenoate thioester in synthesis of HSAF type structures is illustrated in Scheme 3. Not having the tetraene ketone described in Fig. 1, we incubated pentacene 9 with NRPS, ornithine, phosphopantetheinyl transferase, CoA, crude redox enzymes, ATP, and $\mathrm{FAD} / \mathrm{NADH}$ at $30^{\circ} \mathrm{C}$, and the products compared with those resulting from an incubation conducted in the absence of NRPS protein. LC-MS analysis found a variety of products. However, no HSAF analogue was observed.

\section{Discussion and conclusions}

We have developed a practical seven-step synthesis of a biologically relevant dodecapentenoate thioester. Our synthesis, which employs a 3-hydroxy group as a circuit breaker temporarily interrupting the conjugation path, provides a general approach to the creation of polyenoate thioesters. In vitro biosynthetic assays did not observe conversion of the dodecapentaenoate SNAC into HSAF. The results could indicate the need to optimize the assay conditions to stabilize the sensitive 


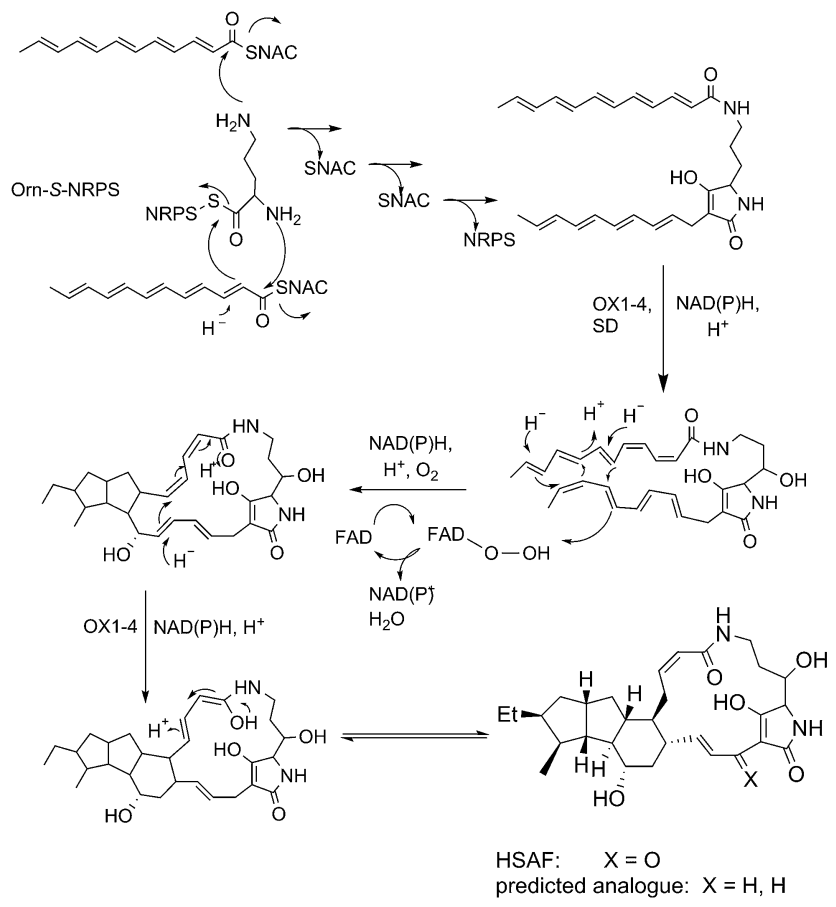

Scheme 3 A proposed pathway for in vitro biosynthesis of an HSAF analogue from thioester 9 .

pentaenoate. Alternatively, the biosynthesis of HSAF could require both polyunsaturated substrates (Fig. 1) to be tethered to the acyl carrier protein of PKS. ${ }^{21}$

\section{Experimental procedures}

All reactions were conducted under an atmosphere of $\mathrm{N}_{2}$ in flame-dried glassware. Any molecule with four or more double bonds was kept in total/near total darkness whenever possible; a red headlamp was used to provide temporary light during addition of reagents, reaction monitoring, work-up, and chromatography. All reagents and solvents were used as supplied commercially, except $\mathrm{CH}_{2} \mathrm{Cl}_{2}$ (distilled from $\mathrm{CaH}_{2}$ ) and THF (distilled from $\mathrm{Na}$ /benzophenone). Following extractions, organic layers were dried using sodium sulfate and filtered through a cotton plug. ${ }^{1} \mathrm{H}$ NMR and ${ }^{13} \mathrm{C}$ NMR spectra were acquired in $\mathrm{CDCl}_{3}$ or $d_{8}$-THF at the described spectrometer frequency. Chemical shifts are reported relative to residual chloroform (7.26 ppm for ${ }^{1} \mathrm{H}$ and $77.0 \mathrm{ppm}$ for ${ }^{13} \mathrm{C}$ ). IR spectra were obtained on neat films (ZnSe, ATR mode) with selected absorbance's reported in wavenumbers $\left(\mathrm{cm}^{-1}\right)$. UV-Vis spectra were obtained over the range of $250-800 \mathrm{~nm}$ (1 nm interval, $340 \mathrm{~nm}$ light source, $0.5 \mathrm{~nm}$ slit width) with selected absorbance's reported in nanometers. Flash column chromatography was performed on $230-400 \mu \mathrm{M}$ silica gel. Thin-layer chromatography (TLC) was performed on $0.25 \mathrm{~mm}$ hard-layer silica $\mathrm{G}$ plates containing a fluorescent indicator; developed TLC plates were visualized with a hand-held UV lamp or by heating after staining with $1 \%$ potassium permanganate in $\mathrm{H}_{2} \mathrm{O}$ solution (olefin dip). Abbreviations throughout: EA = ethyl acetate; Hex $=$ hexane.

\section{$(2 E, 4 E, 6 E)-N$-Methoxy- $N$-methyl-octa-2,4,6-trienamide}

A solution of 2-diethoxyphosphoryl- $N$-methoxy- $N$-methylacetamide $(1.00 \mathrm{~g}, 4.18 \mathrm{mmol})$ in $25 \mathrm{~mL}$ of THF was cooled to $0{ }^{\circ} \mathrm{C}$. To this solution $2.75 \mathrm{~mL}(4.4 \mathrm{mmol})$ of $1.6 \mathrm{M} n$-butyl lithium in hexane was added slowly over five minutes. The reaction was allowed to stir for one hour after which $(2 E, 4 E)$ hexa-2,4-dienal $(0.4012 \mathrm{~g}, 4.18 \mathrm{mmol})$ was added. The reaction mixture was allowed to stir for one hour at $0{ }^{\circ} \mathrm{C}$ and then quenched with $20 \mathrm{~mL}$ of sat. aq. $\mathrm{NH}_{4} \mathrm{Cl}$. The resulting solution was then extracted with EA $(3 \times 40 \mathrm{~mL})$. The combined organic extracts were dried and then concentrated under reduced pressure to yield $756 \mathrm{mg}$ (99\%) of 3. $R_{\mathrm{f}}: 0.3(20 \% \mathrm{EA} / \mathrm{Hex}) ;{ }^{1} \mathrm{H}$ NMR (400 MHz): $\delta 1.838(\mathrm{~d}, 3 \mathrm{H}, J=5.2), 3.27(\mathrm{~s}, 3 \mathrm{H}), 3.72(\mathrm{~s}$, $3 \mathrm{H}), 5.93(\mathrm{~m}, 1 \mathrm{H}), 6.16(\mathrm{t}, 1 \mathrm{H}, J=1.2), 6.20(\mathrm{t}, 1 \mathrm{H}, J=1.2), 6.44$ $(\mathrm{t}, 1 \mathrm{H}, J=14.8), 6.55(\mathrm{t}, 1 \mathrm{H}, J=10.4), 7.38(\mathrm{~d}, 1 \mathrm{H}, J=16) ;{ }^{13} \mathrm{C}$ NMR (100 MHz): $\delta 18.57\left(\mathrm{CH}_{3}\right), 32.47\left(\mathrm{CH}_{3}\right), 61.77\left(\mathrm{CH}_{3}\right),\left(\mathrm{CH}_{3}\right)$, $118.05(\mathrm{CH}), 128.6(\mathrm{CH}), 131.2(\mathrm{CH}), 134.8(\mathrm{CH}), 140.51(\mathrm{CH})$, 143.64 (CH), 167.4 (C); IR: 2935, 1649, 1603.39, 1377, 997; HRMS calculated for $\mathrm{C}_{10} \mathrm{H}_{15} \mathrm{NNaO}_{2}(\mathrm{M}+\mathrm{Na})^{+}$: 204.1000; found: 204.1005.

\section{$(2 E, 4 E, 6 E)$-Octa-2,4,6-trienal ${ }^{16}$}

A solution of $\mathrm{Cp}_{2} \mathrm{Zr}(\mathrm{H}) \mathrm{Cl}(1.0742 \mathrm{~g}, 4.18 \mathrm{mmol})$ in $20 \mathrm{~mL}$ of THF was prepared at Rt. To this solution $3756 \mathrm{mg}$ ( $4.18 \mathrm{mmol})$ was added all at once. The reaction was allowed to stir for 1 hour. The reaction was then quenched with $40 \mathrm{~mL}$ of sat. aq. $\mathrm{NH}_{4} \mathrm{Cl}$ solution. The solution was then extracted three times with 50 $\mathrm{mL}$ portions of EA. The resulting solution was then extracted with EA $(3 \times 40 \mathrm{~mL})$, The combined organic extracts were dried and then concentrated under reduced pressure. The residue was then purified by chromatography ( $8 \% \mathrm{EA} / \mathrm{Hex})$ to yield $306 \mathrm{mg}$ ( $2.5 \mathrm{mmol})(60 \%)$ of $4 . R_{\mathrm{f}}: 0.42$ (20\% EA/Hex), ${ }^{1} \mathrm{H}$ NMR (300 MHz): $\delta 1.76(\mathrm{~d}, 3 \mathrm{H}, J=6), 5.95-6.28$ (overlapping peaks, $4 \mathrm{H}), 6.53(\mathrm{t}, 1 \mathrm{H}, J=12), 7.03(\mathrm{t}, 1 \mathrm{H}, J=12), 9.45(\mathrm{~d}, 1 \mathrm{H}, J=6)$; ${ }^{13} \mathrm{C}$ NMR (75 MHz): $\delta 18.62\left(\mathrm{CH}_{3}\right), 127.54(\mathrm{CH}), 130.52(\mathrm{CH})$, $131.14(\mathrm{CH}), 137.09(\mathrm{CH}), 143.12(\mathrm{CH}), 152.43(\mathrm{CH}), 193.36$ (CH); IR: 2912, 1673, 1606, 1434, 1160, 1112, 990; UV-Vis (chloroform) $\lambda_{\max }=319 \mathrm{~nm}, \varepsilon=39000$. HRMS (TOF) calculated for $\mathrm{C}_{8} \mathrm{H}_{10} \mathrm{O}$ : 122.0732; found 122.0727.

\section{$(2 E, 4 E, 6 E, 8 E)-N$-Methoxy- $N$-methyl-deca-2,4,6,8-tetraenamide}

A solution of 2-diethoxyphosphoryl- $N$-methoxy- $N$-methylacetamide $(0.5990 \mathrm{~g}, 2.50 \mathrm{mmol})$ in $25 \mathrm{~mL}$ of THF was prepared. To this solution $1.56 \mathrm{~mL}(2.50 \mathrm{mmol})$ of $1.6 \mathrm{M} n$-butyl lithium in hexane was added slowly over five minutes at $0{ }^{\circ} \mathrm{C}$. The solution was allowed to stir for one hour. To this solution 4 ( $0.306 \mathrm{~g}, 2.50 \mathrm{mmol})$ is added and allowed to stir for one hour. The reaction is then quenched with $20 \mathrm{~mL}$ of sat. aq. $\mathrm{NH}_{4} \mathrm{Cl}$ solution. The resulting solution was then extracted with EA $(3 \times$ $40 \mathrm{~mL}$ ), the combined organic extracts were dried and then concentrated under reduced pressure to yield $518 \mathrm{mg}$ (2.5 mmol) (99\%) of 5. $R_{\mathrm{f}}: 0.3$ (20\% EA/Hex) ${ }^{1} \mathrm{H}$ NMR (300 MHz): $\delta 1.83(\mathrm{~d}, 3 \mathrm{H}, J=9), 3.27(\mathrm{~s}, 3 \mathrm{H}), 3.72(\mathrm{~s}, 3 \mathrm{H}), 5.93(\mathrm{~m}, 1 \mathrm{H}), 5.86$ ( $\mathrm{m}, 1 \mathrm{H}$ ), 6.16 (overlapping peaks, 2H), 6.32-6.48 (overlapping peaks, $3 \mathrm{H}), 6.58(\mathrm{t}, 1 \mathrm{H}, J=6), 7.38(, 1 \mathrm{H}, J=12) ;{ }^{13} \mathrm{C} \mathrm{NMR}$ 
(75 MHz): $\delta 18.53\left(\mathrm{CH}_{3}\right), 32.47\left(\mathrm{CH}_{3}\right), 61.77\left(\mathrm{CH}_{3}\right),\left(\mathrm{CH}_{3}\right), 117.88$ $(\mathrm{CH}), 129.56(\mathrm{CH}), 129.78(\mathrm{CH}), 131.63(\mathrm{CH}), 132.76(\mathrm{CH})$, $136.98(\mathrm{CH}), 140.50(\mathrm{CH}), 143.46(\mathrm{CH}), 167.36$ (C); IR: 3016, 2934, 1643, 1589, 1371, 1001; UV-Vis (chloroform) $\lambda_{\max }=$ $341 \mathrm{~nm}, \varepsilon=44000 \mathrm{HRMS}$ calculated for $\mathrm{C}_{12} \mathrm{H}_{17} \mathrm{NO}_{2}(\mathrm{M}+\mathrm{Na})^{+}$: 230.1157; found 230.1147 .

\section{$(2 E, 4 E, 6 E, 8 E)$-Deca-2,4,6,8-tetraenal ${ }^{16}$}

A solution of $\mathrm{Cp}_{2} \mathrm{Zr}(\mathrm{H}) \mathrm{Cl}(0.6425 \mathrm{~g}, 2.5 \mathrm{mmol})$ in $10 \mathrm{~mL}$ of THF was prepared. To this solution $5(518 \mathrm{mg}, 2.5 \mathrm{mmol})$ was added all at once. The reaction is allowed to stir for one hour. The reaction is then quenched with $10 \mathrm{~mL}$ of sat. aq. $\mathrm{NH}_{4} \mathrm{Cl}$ solution. The resulting solution was then extracted with EA $(3 \times$ $40 \mathrm{~mL}$ ). The combined organic extracts were dried and then concentrated under reduced pressure. The residue is then purified by chromatography (8\% EA/Hex) to yield $111 \mathrm{mg}$ (0.75 mmol) (30\%) of 6. $R_{\mathrm{f}}: 0.42\left(20 \%\right.$ EA/Hex). ${ }^{1} \mathrm{H}$ NMR (300 MHz): $\delta 1.83$ (d, 3H, $J=6$ ), $5.93(\mathrm{~m}, 1 \mathrm{H}), 6.09-6.26$ (overlapping peaks, 3H), 6.41-6.45 (overlapping peaks, $2 \mathrm{H}), 6.68(\mathrm{t}$, $1 \mathrm{H}, J=12), 7.13(\mathrm{t}, 1 \mathrm{H}, J=9), 9.55(\mathrm{~d}, 1 \mathrm{H}, J=6) ;{ }^{13} \mathrm{C} \mathrm{NMR}$ (75 MHz): $\delta 18.59\left(\mathrm{CH}_{3}\right), 129.04(\mathrm{CH}), 129.15(\mathrm{CH}), 130.56(\mathrm{CH})$, $131.54(\mathrm{CH}), 134.42(\mathrm{CH}), 139.18(\mathrm{CH}), 143.08(\mathrm{CH}), 152.05$ (CH), 193.44 (C); IR: 3020, 2907, 2814, 1660, 1583, 1108, 97; UVVis (chloroform) $\lambda_{\max }=348 \mathrm{~nm}, \varepsilon=52000$; HRMS (TOF) calculated for $\mathrm{C}_{10} \mathrm{H}_{11} \mathrm{O}$ : 148.0888; found 148.0893.

\section{(4E,6E,8E,10E)-3-Hydroxydodeca-4,6,8,10-tetraenoic acid}

A solution of diisopropylamine $(0.1513 \mathrm{~g}, 1.496 \mathrm{mmol})$ in $5 \mathrm{~mL}$ of THF was prepared at $0{ }^{\circ} \mathrm{C}$. To this solution $0.935 \mathrm{~mL}$ of $1.6 \mathrm{M}$ $n$-butyl lithium $(1.496 \mathrm{mmol})$ in hexane was added. The solution is allowed to stir for 15 minutes. Dry glacial acetic acid $(0.0408 \mathrm{~g}$, $0.68 \mathrm{mmol}$ ) was added and allowed to stir for 1 hour. A separate solution was prepared containing $6(100 \mathrm{mg}, 0.68 \mathrm{mmol})$ in $5 \mathrm{~mL}$ of THF at $0{ }^{\circ} \mathrm{C}$. The first solution containing the deprotonated acetic acid was slowly added to the second solution over the course of 10 minutes. The reaction was then allowed to incubate for one hour. The reaction is then quenched with $5 \mathrm{~mL}$ of aq. $1 \mathrm{M} \mathrm{HCl}$. The resulting solution was then extracted with $5: 1 \mathrm{EA} / \mathrm{THF}(3 \times 20 \mathrm{~mL})$, The organic extracts were then combined washed with $50 \mathrm{~mL}$ of sat. aq. $\mathrm{NaCl}$, dried, filtered and concentrated under reduced pressure to yield $141.6 \mathrm{mg}$ $(0.68 \mathrm{mmol})(99 \%)$ of $7 .{ }^{1} \mathrm{H}$ NMR (400 MHz): $\delta 2.37$ (d, $2 \mathrm{H}, J=$ 6.8 ), 4.47 (q, $1 \mathrm{H}, J=6$ ), 5.64-5.74 (overlapping peaks, $2 \mathrm{H}$ ), 6.056.19 (overlapping peaks, 6H); ${ }^{13} \mathrm{C}$ NMR (100 MHz): $\delta 18.55$ $\left(\mathrm{CH}_{3}\right), 42.99\left(\mathrm{CH}_{2}\right), 69.12(\mathrm{CH}), 130.12(\mathrm{CH}), 130.57(\mathrm{CH}), 131.60$ $(\mathrm{CH}), 132.86(\mathrm{CH}), 133.23(\mathrm{CH}), 133.68(\mathrm{CH}), 134.02(\mathrm{CH})$, $137.00(\mathrm{CH}), 172.9 .44(\mathrm{C})$; UV-Vis (THF) $\lambda_{\max }=300 \mathrm{~nm}, \varepsilon=$ 40 000. A sample was derivatized with trimethylsilyldiazomethane to form the methyl ester, which was then subjected to analysis. HRMS $(\mathrm{M}+\mathrm{Na})^{+}$calculated for $\mathrm{C}_{13} \mathrm{H}_{18} \mathrm{O}_{3}$ : 245.1154; found 245.1148 .

\section{$S$-(2-Acetamidoethyl) $(4 E, 6 E, 8 E, 10 E)-3$-hydroxydodeca-4,6,8,10- tetraenethioate}

A solution of $7(0.141 \mathrm{~g}, 0.68 \mathrm{mmol})$ in $10 \mathrm{~mL}$ of THF was prepared at RT. To this solution DMAP $(0.0083 \mathrm{~g}, 0.068 \mathrm{mmol})$ and SNAC (0.0810 g, $0.68 \mathrm{mmol})$ were added. To this solution EDCI $(0.1055 \mathrm{~g}, 0.68 \mathrm{mmol})$ is added all at once. After being allowed to stir for four hours the solution is then quenched with $20 \mathrm{~mL}$ of sat. aq. $\mathrm{NH}_{4} \mathrm{Cl}$. The resulting solution was then extracted with EA $(3 \times 40 \mathrm{~mL})$, the organic extracts were then combined and washed with $10 \mathrm{~mL}$ of $0.5 \mathrm{M}$ aq. $\mathrm{HCl}$, washed with $10 \mathrm{~mL}$ of sat. aq. sodium bicarbonate and finally washed with $20 \mathrm{~mL}$ sat. aq. $\mathrm{NaCl}$. The combined organic extracts were dried and then concentrated under reduced pressure to yield $105 \mathrm{mg}$ ( $0.34 \mathrm{mmol})$ (50\%) of 8 which was used without further purification. ${ }^{1} \mathrm{H}$ NMR (400 MHz): $\delta 1.78(\mathrm{~d}, 3 \mathrm{H}), 1.95(\mathrm{~s}, 3 \mathrm{H}), 2.80$ (d, 2H), $3.04(\mathrm{~m}, 2 \mathrm{H}), 3.42(\mathrm{~m}, 2 \mathrm{H}), 4.66(\mathrm{~m}, 1 \mathrm{H})$ 5.67-5.75 (overlapping peaks, $2 \mathrm{H}$ ), 6.08-6.32 (overlapping peaks, $6 \mathrm{H}$ ); ${ }^{13} \mathrm{C}$ NMR (100 MHz): $\delta 18.39\left(\mathrm{CH}_{3}\right), 23.17\left(\mathrm{CH}_{3}\right), 38.57\left(\mathrm{CH}_{2}\right), 44.03$ $\left(\mathrm{CH}_{2}\right), 51.05\left(\mathrm{CH}_{2}\right), 69.26(\mathrm{CH}), 129.92(\mathrm{CH}), 130.62(\mathrm{CH}), 130.79$ $(\mathrm{CH}), 131.38(\mathrm{CH}), 131.72(\mathrm{CH}), 132.81(\mathrm{CH}), 134.11(\mathrm{CH})$, $134.22(\mathrm{CH}), 170.65(\mathrm{C}), 198.26(\mathrm{C})$; UV-Vis (chloroform) $\lambda_{\max }=$ $304 \mathrm{~nm}, \varepsilon=42000$. HRMS $(\mathrm{M}+\mathrm{Na})^{+}$calculated for $\mathrm{C}_{16} \mathrm{H}_{23} \mathrm{NO}_{3} \mathrm{~S}$ : 332.1297; found 332.1296.

\section{$S$-(2-Acetamidoethyl) $(2 E, 4 E, 6 E, 8 E, 10 E)$-dodeca-2,4,6,8,10- pentaenethioate}

A To a solution of $8(0.060 \mathrm{~g}, 0.194 \mathrm{mmol})$ in $10 \mathrm{~mL} \mathrm{CH}_{2} \mathrm{Cl}_{2}$ at RT was added methyl sulfonyl chloride $(0.044 \mathrm{~g}, 0.388 \mathrm{mmol})$ along with $\mathrm{NEt}_{3}(0.0784 \mathrm{~g}, 0.776 \mathrm{mmol})$. The solution was allowed to incubate for 48 hours. The reaction was then quenched with $20 \mathrm{~mL}$ of sat. aq. $\mathrm{NH}_{4} \mathrm{Cl}$. The resulting solution was then extracted with $\mathrm{CH}_{2} \mathrm{Cl}_{2}(3 \times 40 \mathrm{~mL})$. The $\mathrm{CH}_{2} \mathrm{Cl}_{2}$ is washed with $10 \mathrm{~mL}$ of sat. aq. sodium bicarbonate and finally washed with $10 \mathrm{~mL}$ sat. aq. $\mathrm{NaCl}$. The combined organic extracts were dried and then concentrated under reduced pressure to yield to yield $17 \mathrm{mg}(0.0582 \mathrm{mmol})(30 \%)$ of 9. $R_{\mathrm{f}}: 0.72\left(5 \% \mathrm{MeOH} / \mathrm{CH}_{2} \mathrm{Cl}_{2}\right) \cdot{ }^{1} \mathrm{H}$ NMR (400 MHz): $\delta 1.82(\mathrm{~d}, 3 \mathrm{H}), 1.98(\mathrm{~s}, 3 \mathrm{H}), 3.14(\mathrm{~m}, 2 \mathrm{H}), 3.48$ (m, 2H), 5.84-5.88 (overlapping peaks, 2H), 6.15-6.36 (overlapping peaks, $7 \mathrm{H}), 6.72(\mathrm{t}, 1 \mathrm{H}) ;{ }^{13} \mathrm{C} \mathrm{NMR}(100 \mathrm{MHz}): \delta 18.55$ $\left(\mathrm{CH}_{3}\right), 22.94\left(\mathrm{CH}_{3}\right), 31.55\left(\mathrm{CH}_{2}\right), 39.99\left(\mathrm{CH}_{2}\right), 126.49(\mathrm{CH})$, $128.93(\mathrm{CH}), 129.37(\mathrm{CH}), 130.94(\mathrm{CH}), 131.77(\mathrm{CH}), 132.73$ $(\mathrm{CH}), 133.73(\mathrm{CH}), 136.69(\mathrm{CH}), 138.61(\mathrm{CH}), 141.47(\mathrm{CH})$, 143.22 (C), 189.97 (C); UV-Vis (chloroform) $\lambda_{\max }=380 \mathrm{~nm}, \varepsilon=$ 60 000; HRMS $(\mathrm{M}+\mathrm{Na})^{+}$calculated for $\mathrm{C}_{16} \mathrm{H}_{21} \mathrm{NO}_{2} \mathrm{~S}$ : 314.1191; found 314.1193 .

\section{In vitro assay for the activity of NRPS using the pentaenoic acid thioester substrate}

NRPS needs to be converted to its holo-form by a promiscuous 4'-phosphopantetheinyl transferase (PPTase), Svp, by incubating with coenzyme A. The holo-NRPS was obtained by incubating protein $(3 \mu \mathrm{M})$ and $\operatorname{CoA}(0.83 \mathrm{mM})$ with $\operatorname{Svp}(5.6 \mu \mathrm{M})$ in a $60 \mu \mathrm{L}$ reaction containing Tris- $\mathrm{HCl}(100 \mathrm{mM}, \mathrm{pH} 8.0)$, $\mathrm{MgCl}_{2}(10 \mathrm{mM})$, and TCEP $(0.5 \mathrm{mM})$. Reaction was incubated at $37^{\circ} \mathrm{C}$ for $2 \mathrm{~h}$. Finally, the reaction mixture was combined into a tube containing a $40 \mu \mathrm{L}$ solution containing L-orn $(1.5 \mathrm{mM})$, ATP (3 mM), Tris-HCl (100 mM, pH 8.0), $\mathrm{MgCl}_{2}(10 \mathrm{mM}), \mathrm{NaCl}$ (50 $\mathrm{mM})$, EDTA $(0.1 \mathrm{mM})$, and TCEP $(0.5 \mathrm{mM})$. A reaction without NRPS served as the control. The cell free extract (CFE) extracted from $\triangle \mathrm{PKS}$ mutant was considered to provide crude 
redox enzymes, which catalyse the 5,5,6-tricyclic ring system formation in HSAF, coupled with $0.5 \mathrm{mM} \mathrm{FAD/NADH.} \mathrm{The}$ pentaenoate thioester was added right away in a dark room, to make a final concentration of $0.5 \mathrm{mM}$. After continual incubation overnight at $30{ }^{\circ} \mathrm{C}$, the reactions were stopped by adding $150 \mu \mathrm{L}$ of $0.2 \mathrm{mM}$ TCA in methanol and were frozen at $-20^{\circ} \mathrm{C}$ for $30 \mathrm{~min}$. The mixtures were centrifuged at $13200 \mathrm{rpm}$ for 20 min in a desktop Eppendorf centrifuge, and the supernatants were transferred to new tubes. The solutions were dried in a Speed-Vac, and the residues in the tubes were re-dissolved in $20 \mu \mathrm{L}$ methanol, and analyzed by Agilent LC-1200 (Santa Clara, CA) connected to a $2.1 \times 100 \mathrm{~mm}$ Symmetry ODS column from Waters (Milford, MA) and a Triple Quadrupole Mass Spectrometer model 4000 QTrap from ABSciex (Framingham, MA) operating in either single quadrupole (Q1), enhanced mass spectrum (EMS), MS/MS or multiple reaction monitoring (MRM) modes. The samples were injected onto the column and a gradient from $98 \%$ mobile phase $\mathrm{A}(0.1 \%$ formic acid in water, J.T. Baker) to $60 \% \mathrm{~B}(0.1 \%$ formic acid in acetonitrile, Acros Organics) was run over 15 minutes, followed by 5 minutes of $98 \% \mathrm{~B}$ and $5 \mathrm{~min}$ of $98 \% \mathrm{~A}$, all at a flow rate of $0.25 \mathrm{~mL} \mathrm{~min}^{-1}$.

\section{Acknowledgements}

We thank Prof. Martha Morton for technical assistance and Prof. Andrzej Rajca for useful discussions. Research was supported by NIH (R01 AI097260) and conducted in facilities renovated with support from NIH (RR016544).

\section{Notes and references}

1 L. Lou, G. Qian, Y. Xie, J. Hang, H. Chen, K. Zaleta-Rivera, Y. Li, Y. Shen, P. H. Dussault and L. Du, J. Am. Chem. Soc., 2011, 133, 643.

2 S. V. Ley, S. C. Smith and P. R. Woodward, Tetrahedron, 1992, 48, 1145.

3 S. Rychnovsky, Chem. Rev., 1995, 95, 2021.

4 J. Bisceglia and L. Orelli, Curr. Org. Chem., 2012, 16, 2206.
5 H. Sun, R. Kong, D. Zhu, M. Lu, Q. Ji, C. W. Liew, J. Lescar, G. Zhong and Z.-X. Liang, Chem. Commun., 2009, 7399.

6 T. den Hartog, D. J. van Dijken, A. J. Minnaard and B. L. Feringa, Tetrahedron: Asymmetry, 2010, 21, 1574.

7 M. Zeeshan, H.-R. Sliwka, V. Partali and A. Martinez, Org. Lett., 2012, 14, 5496.

8 B. Carrow and K. Nozaki, J. Am. Chem. Soc., 2012, 134, 8802. 9 B. Borhan, M. L. Souto, J. M. Um, B. Zhou and K. Nakanishi, Chem.-Eur. J., 1999, 5, 1172.

10 N. Miyaura and A. Suzuki, Chem. Rev., 1995, 95, 2457.

11 B. Lipshutz and C. Lindsley, J. Am. Chem. Soc., 1997, 119, 4555.

12 J. M. Williams and G. J. McGarvey, Tetrahedron Lett., 1985, 26, 4891.

13 E. Reynaud, G. Aydemir, R. Rühl, O. Dangles and C. CarisVeyrat, J. Agric. Food Chem., 2011, 59, 1457.

14 (a) A. B. Lowe, Polym. Chem., 2010, 1, 17; (b) A. B. Lowe, Polym. Chem., 2014, 5, 4820; (c) C. E. Hoyle and C. N. Bowman, Angew. Chem., Int. Ed., 2010, 49, 1540.

15 J. Nuzillard, A. Boumendjel and G. Massiot, Tetrahedron Lett., 1989, 30, 3779.

16 J. T. Spletstoser, J. M. White, A. R. Tunoori and G. I. Georg, J. Am. Chem. Soc., 2007, 129, 3408.

17 E. J. Lenardao, R. G. Lara, M. S. Silva, R. G. Jacob and G. Perin, Tetrahedron Lett., 2007, 48, 7668.

18 J. C. Love, L. A. Estroff, J. K. Kriebel, R. G. Nuzzo and G. M. Whitesides, Chem. Rev., 2005, 105, 1103.

19 P. Miéville, P. Ahuja, R. Sarkar, S. Jannin, P. R. Vasos, S. Gerber-Lemaire, M. Mishkovsky, A. Comment, R. Gruetter, O. Ouari, P. Tordo and G. Bodenhausen, Angew. Chem., Int. Ed., 2010, 49, 6182 (corrigendum 2010, 49, 7834).

20 V. V. Khramtsov, A. Reznikov, L. J. Berliner, A. K. Litkin, I. A. Grigor'ev and T. L. Clanton, Free Radical Biol. Med., 2001, 30, 1099.

21 Y. Li, H. Chen, Y. Ding, Y. Xie, H. Wang, R. L. Cerny, Y. Shen and L. Du, Angew. Chem., 2014, 53, 7524. 


\section{SUPPORTING INFORMATION}

\section{Synthesis of a 2,4,6,8,10-dodecapentanoic acid thioester as a substrate for biosynthesis of Heat Stable Antifungal Factor (HSAF)}
A. S. Olson, H. Chen, L. Du, and P. H. Dussault*
${ }^{1} \mathrm{H}$ and ${ }^{13} \mathrm{C}$ NMR data page
$(2 E, 4 E, 6 E)-N$-Methoxy-N-methyl-octa-2,4,6-trienamide
$((2 E, 4 E, 6 E)$-Octa-2,4,6-trienal
$(2 E, 4 E, 6 E, 8 E)-N$-Methoxy-N-methyl-deca-2,4,6,8-tetraenamide
$(2 E, 4 E, 6 E, 8 E)$-Deca-2,4,6,8-tetraenal
(4E,6E,8E,10E)-3-Hydroxydodeca-4,6,8,10-tetraenoic acid
S-(2-Acetamidoethyl) $(4 E, 6 E, 8 E, 10 E)$-3-hydroxydodeca-4,6,8,10-tetraenethioate 
${ }^{1} \mathrm{H}$ NMR of (3)
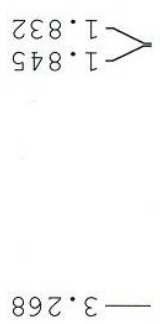

IZL $\cdot \mathcal{-}$
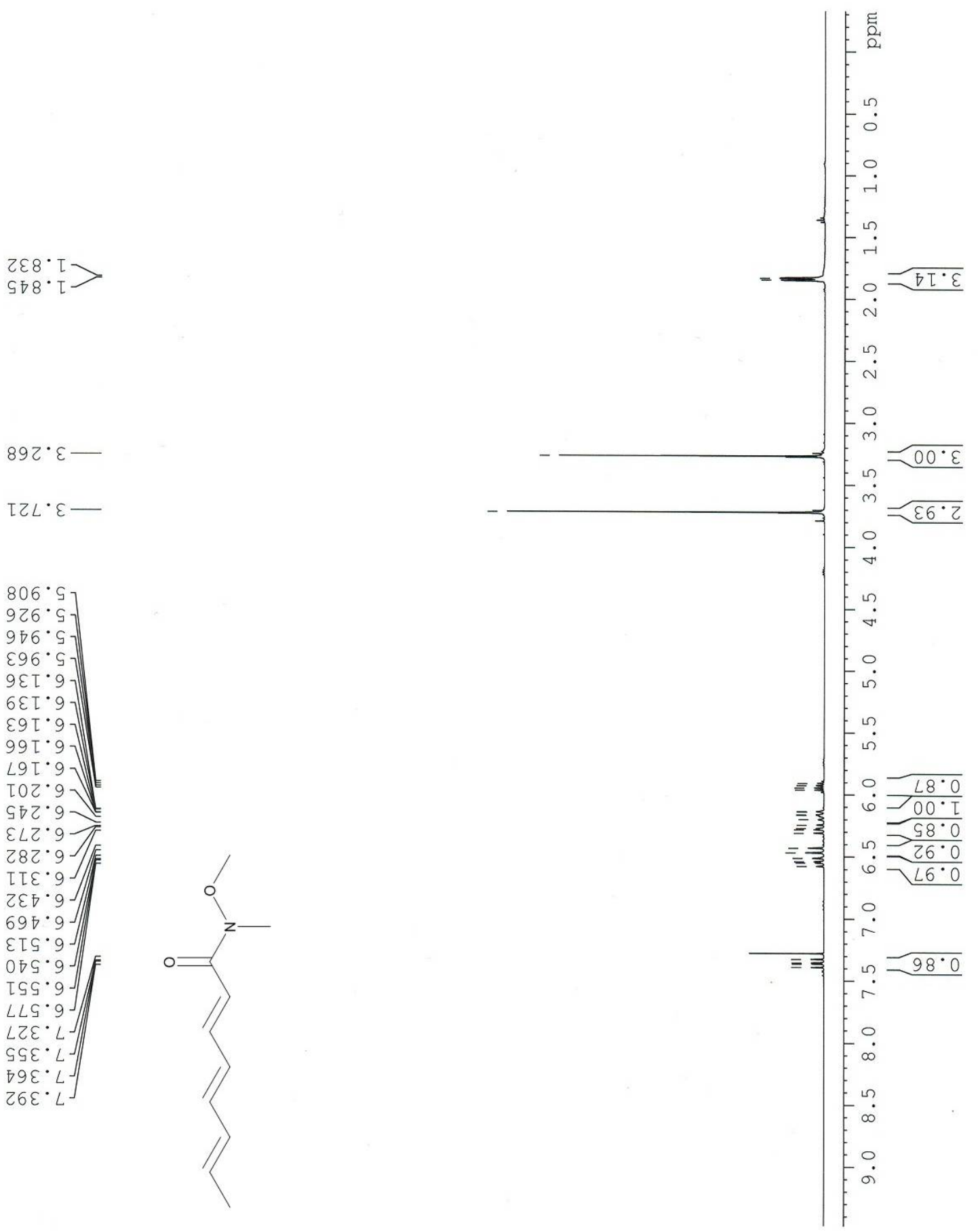
${ }^{13}$ C NMR of (3)
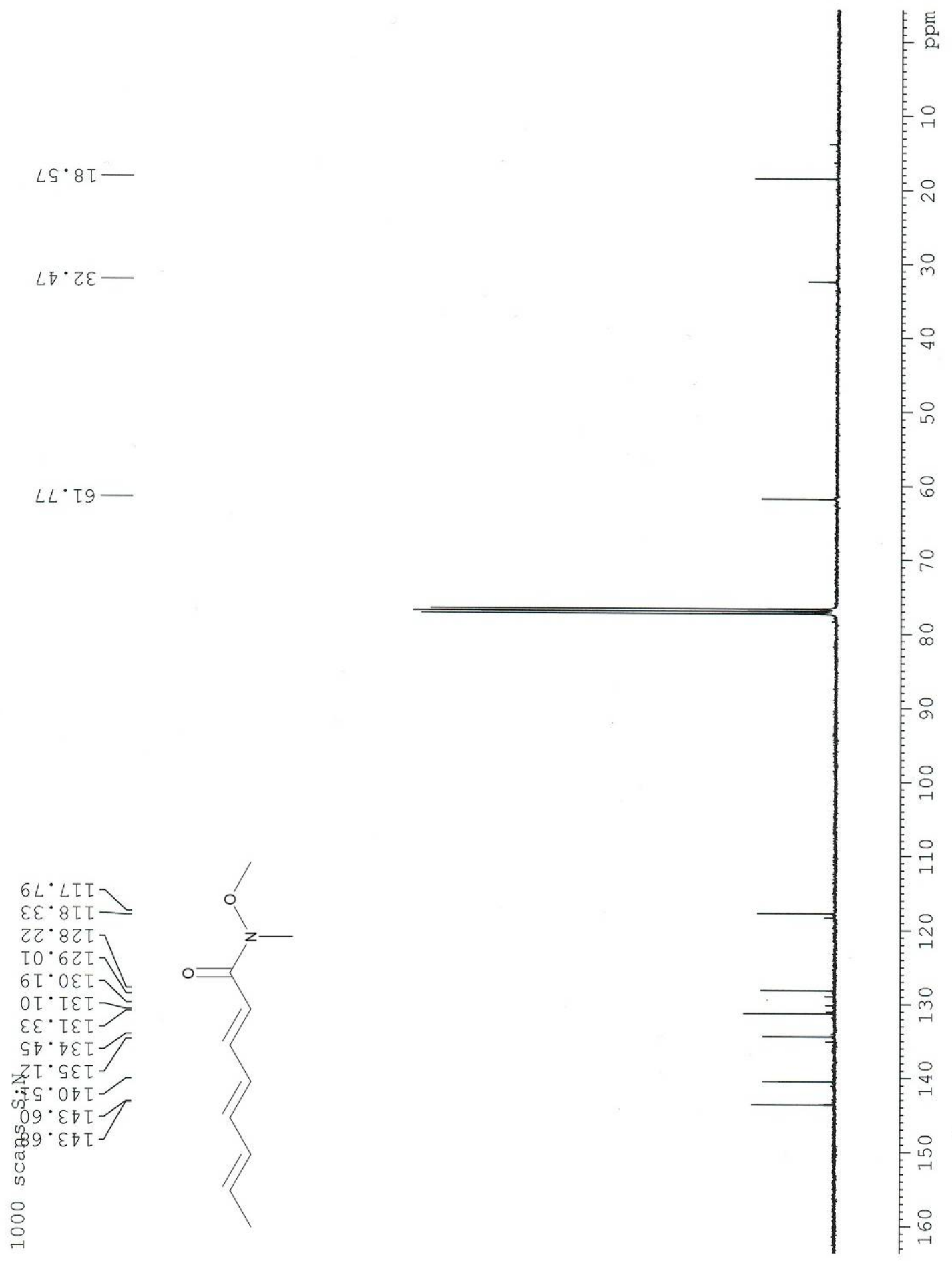
${ }^{1} \mathrm{H}$ NMR of (4)

$96 L^{\circ} I \supset$
$89 L^{\circ}$

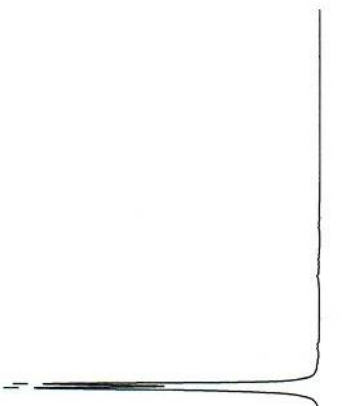

5
$-\frac{1}{2}$

ㄴ.

$\circ$

ㅇ.

ㄴ?

-

$2 \tau \cdot \varepsilon$
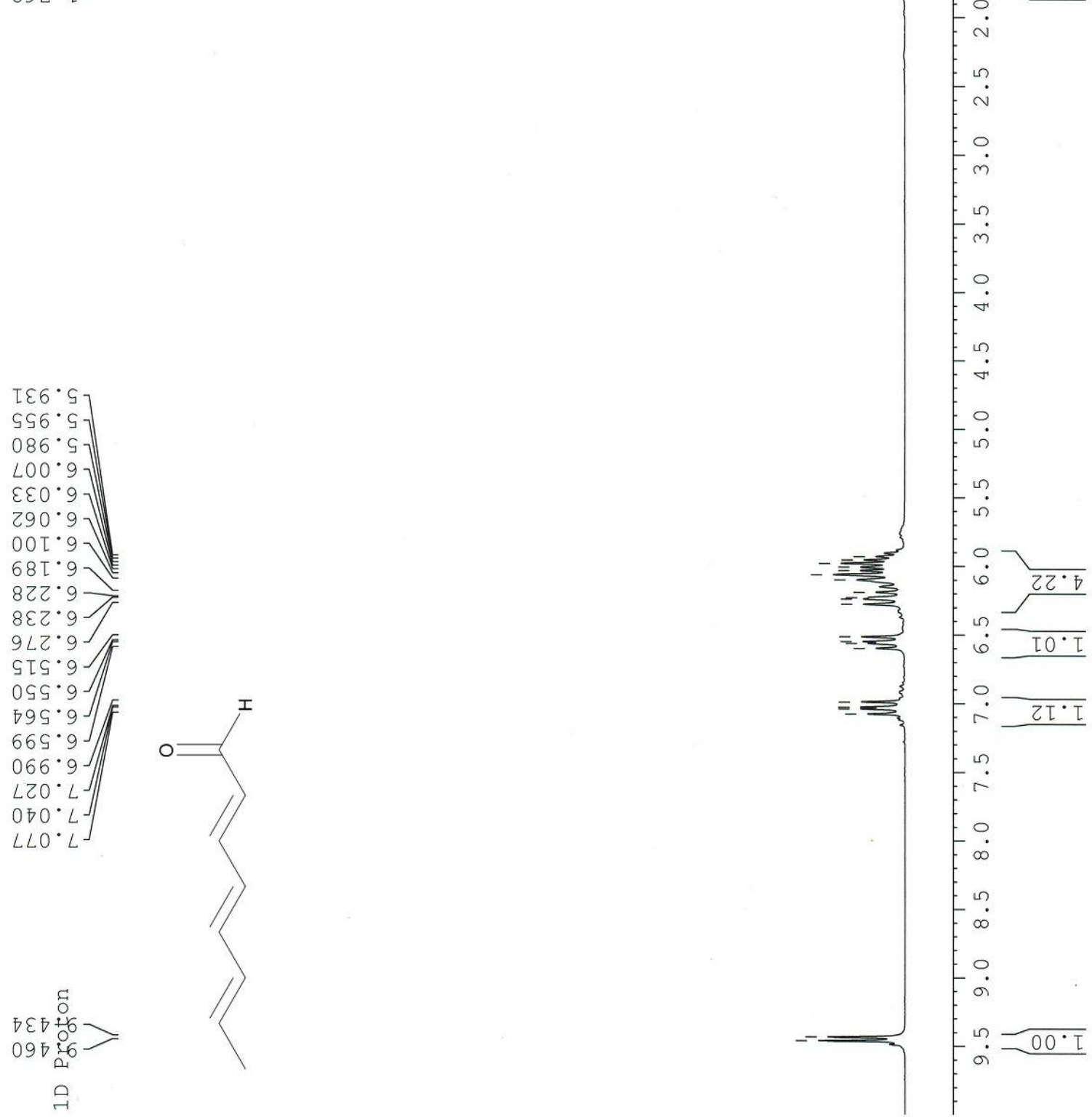
${ }^{13}$ C NMR of (4)
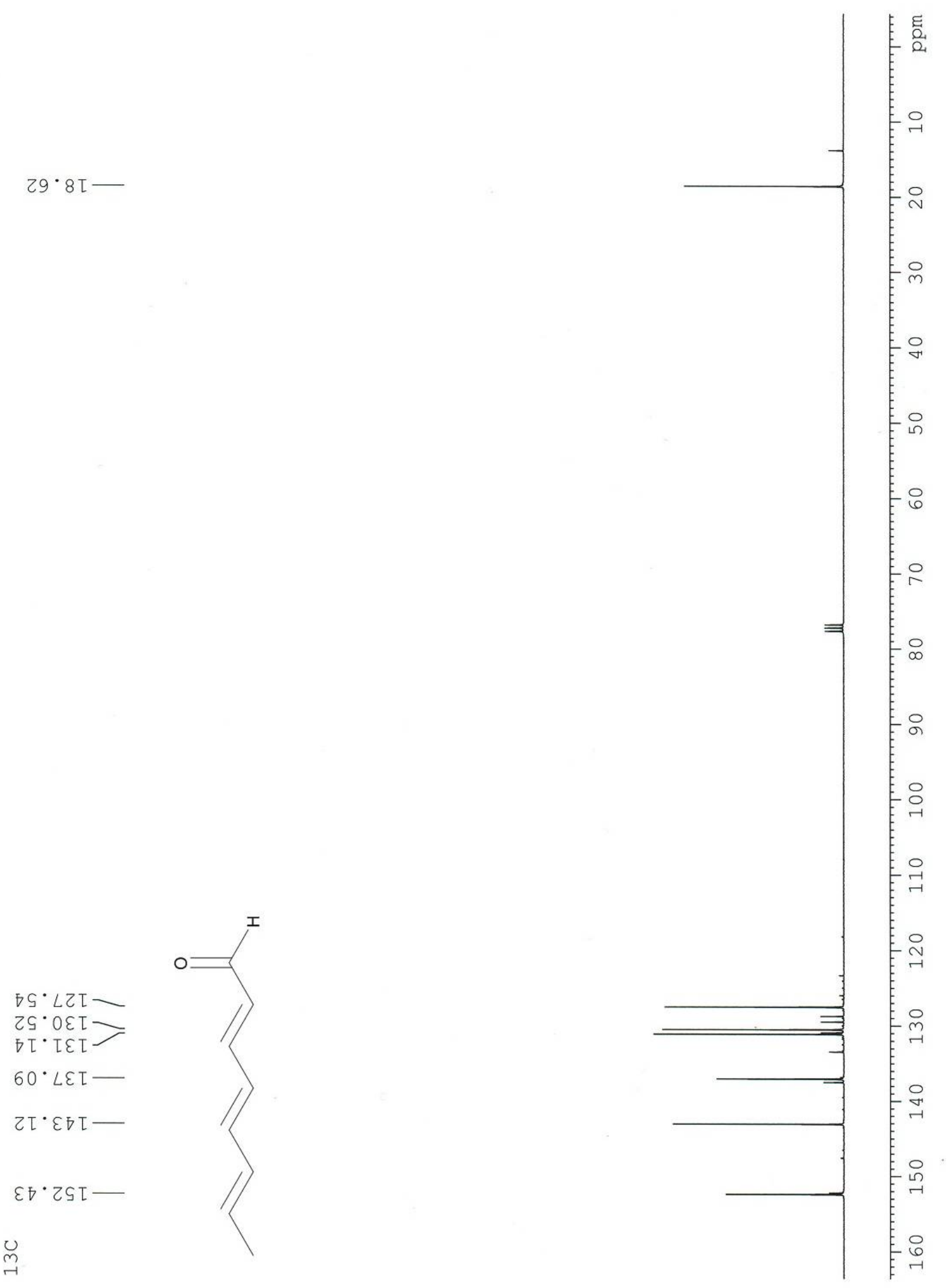
${ }^{1} \mathrm{H}$ NMR of (5)
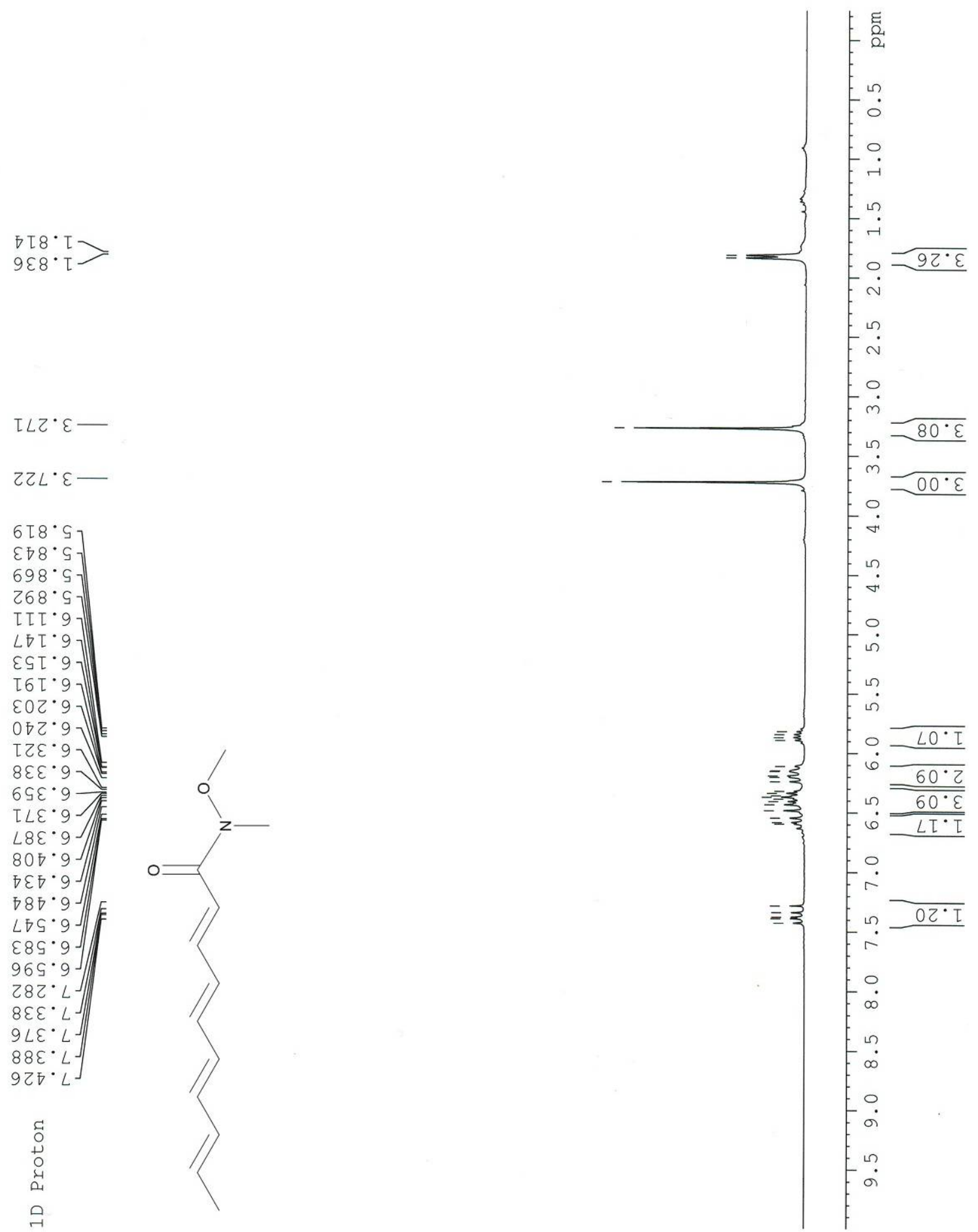
${ }^{13}$ C NMR of (5)
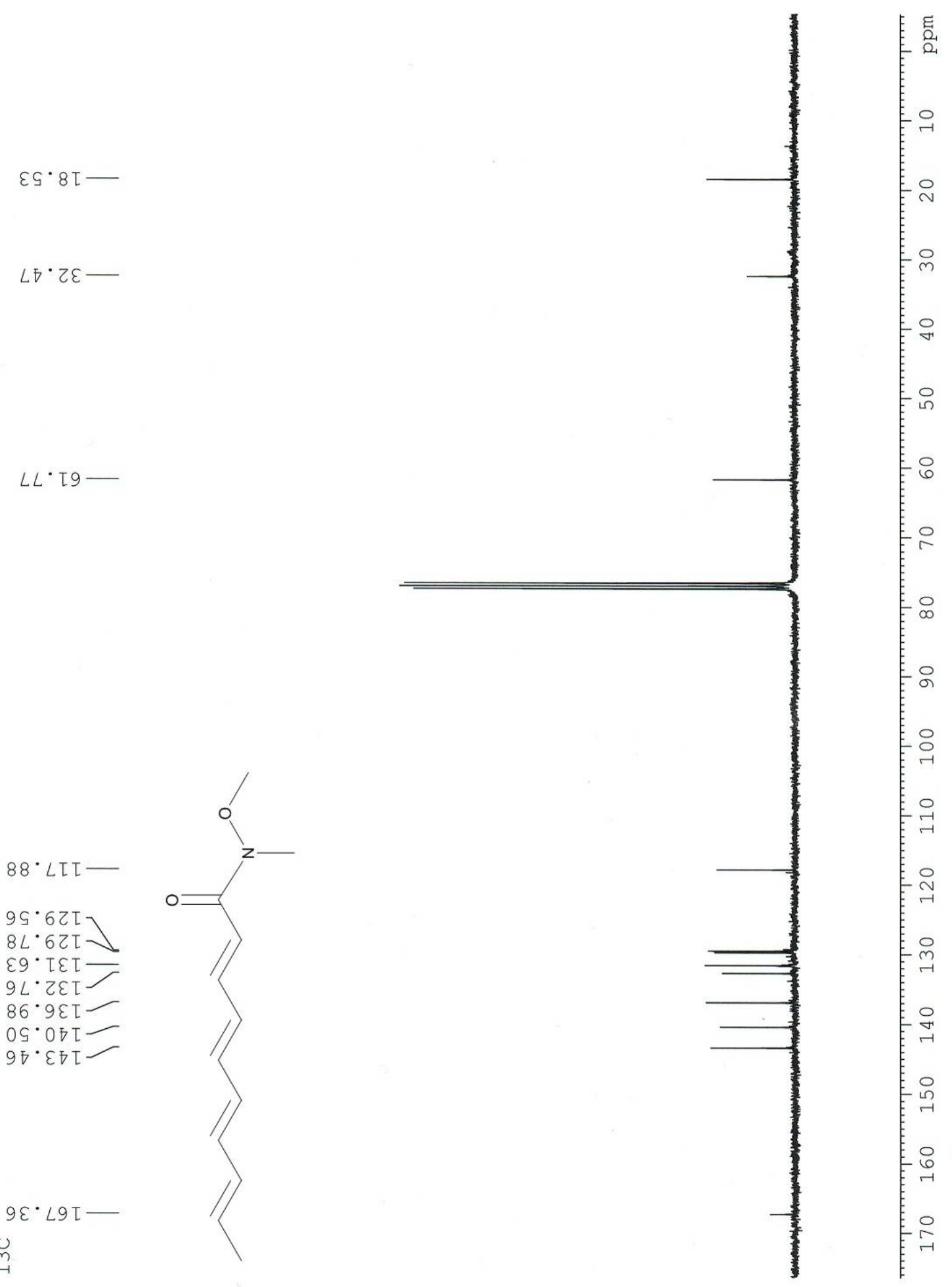
${ }^{1} \mathrm{H}$ NMR of (6)
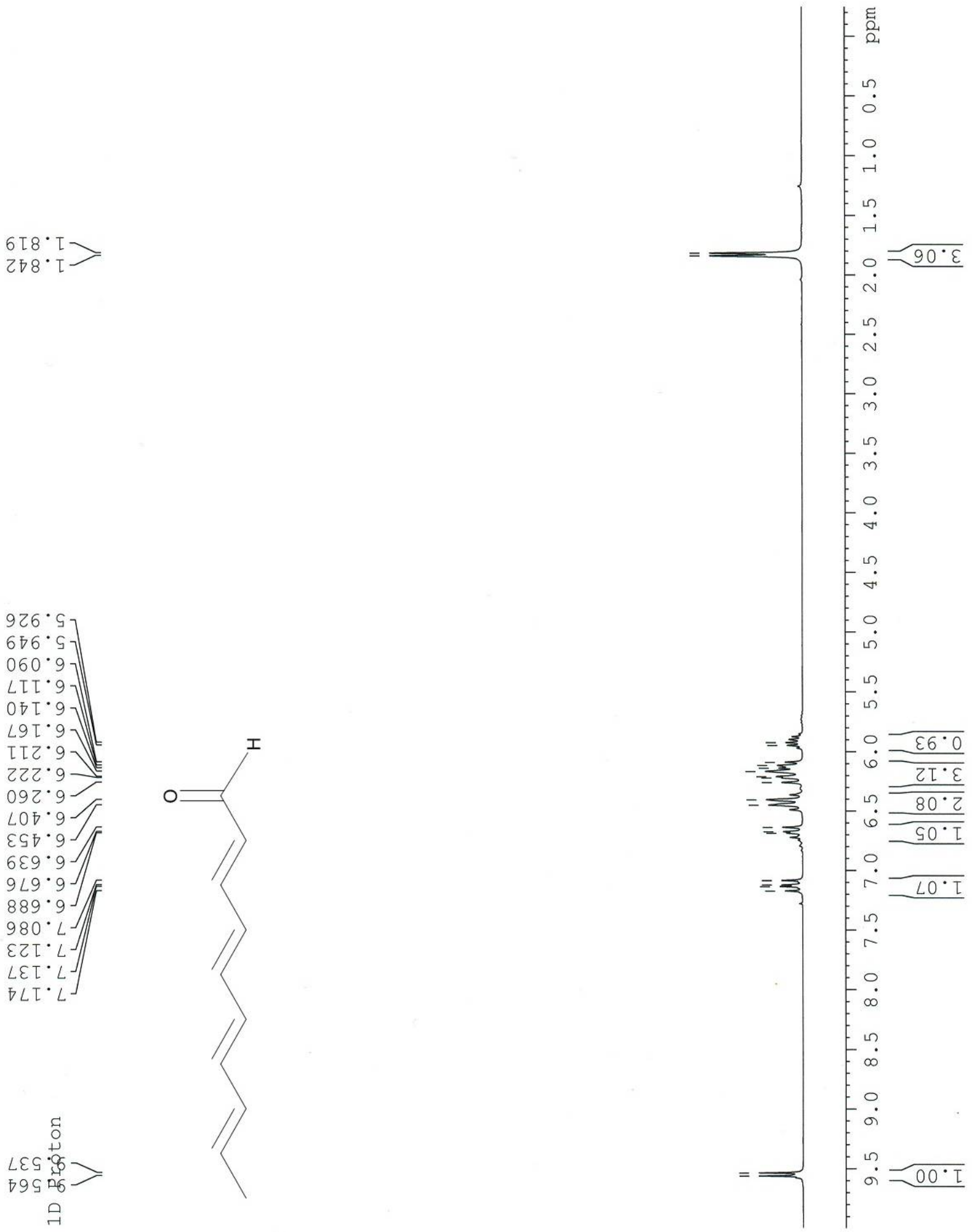
${ }^{13}$ C NMR of (6)
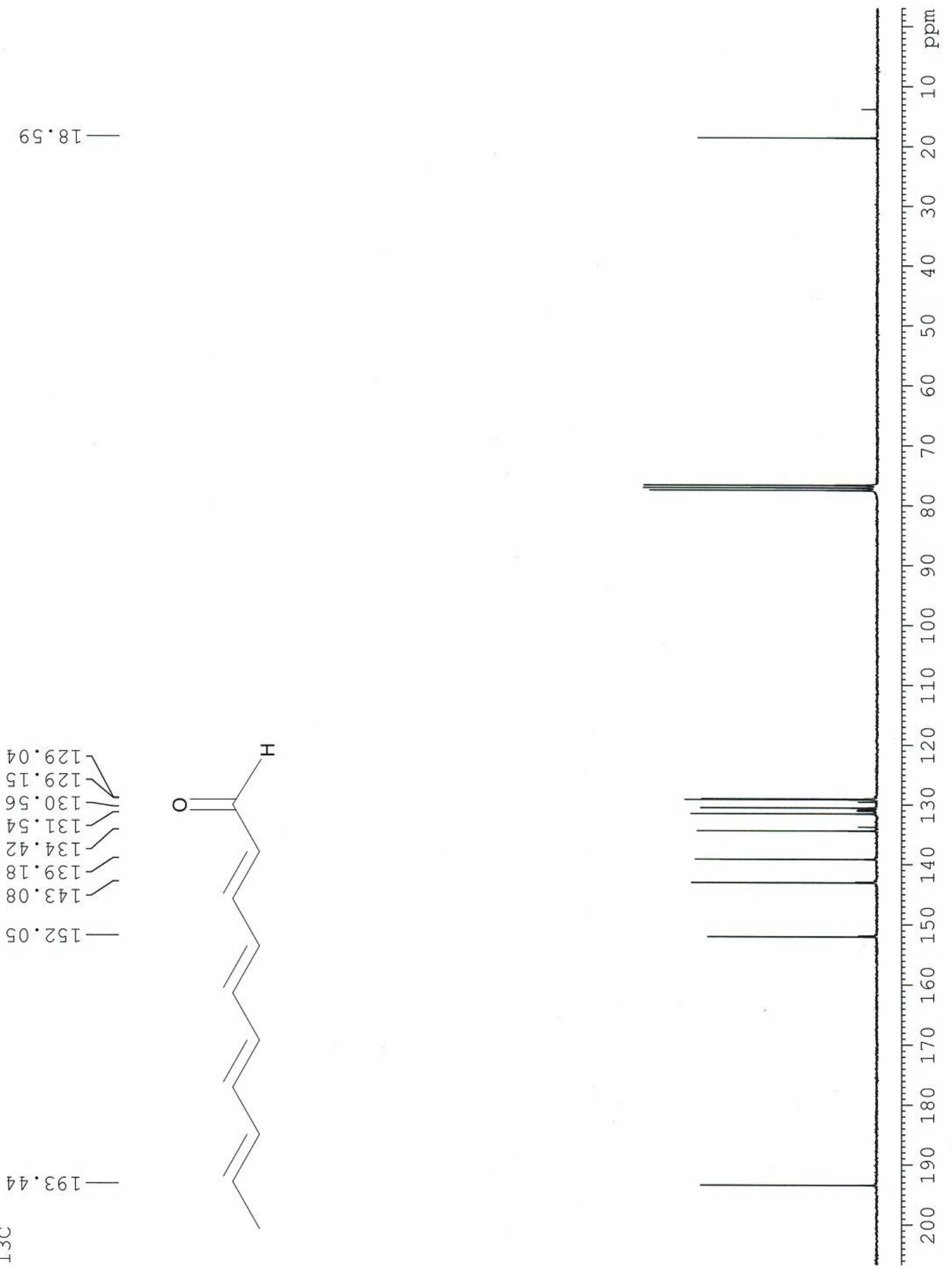
${ }^{1} \mathrm{H}$ NMR of (7)

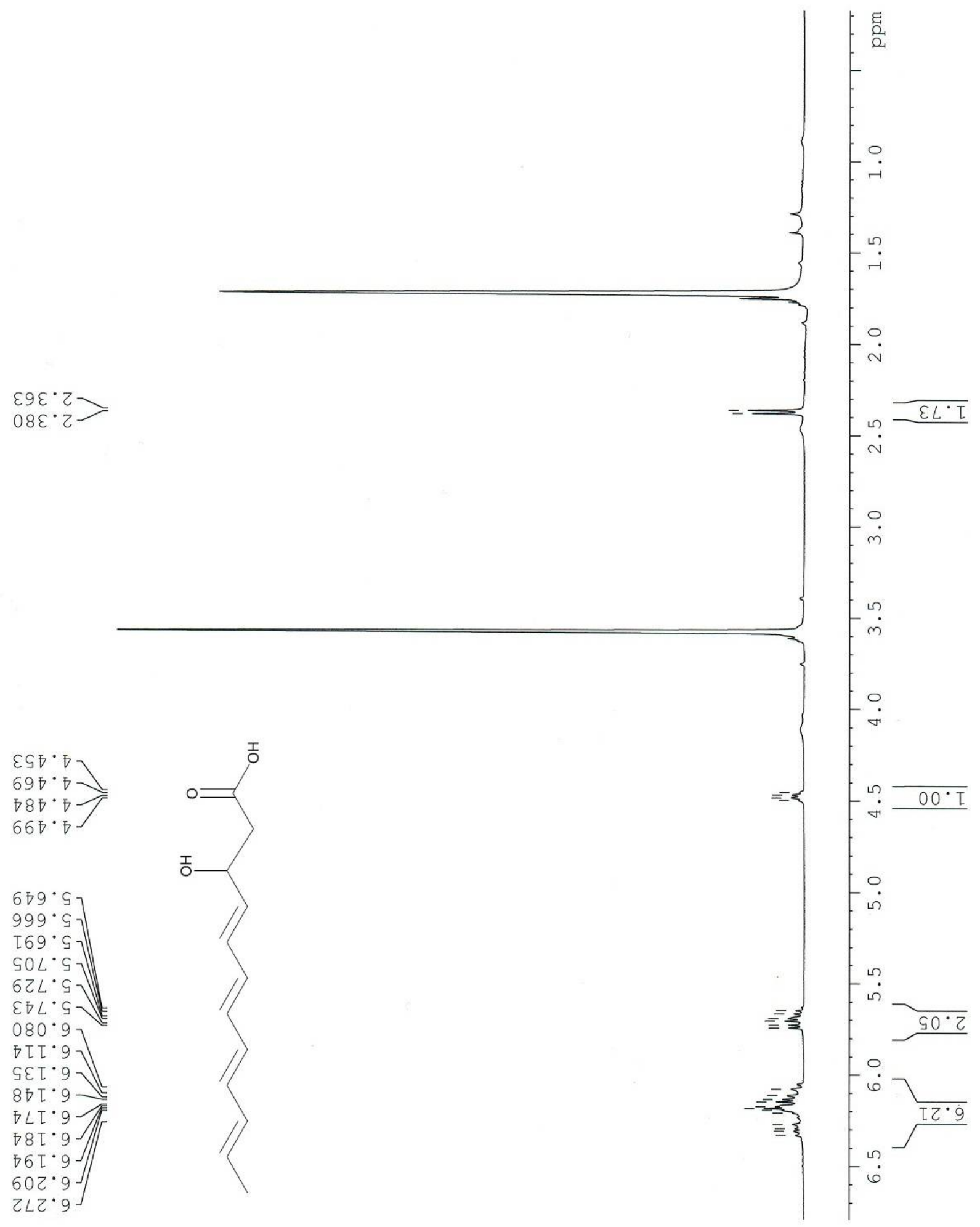




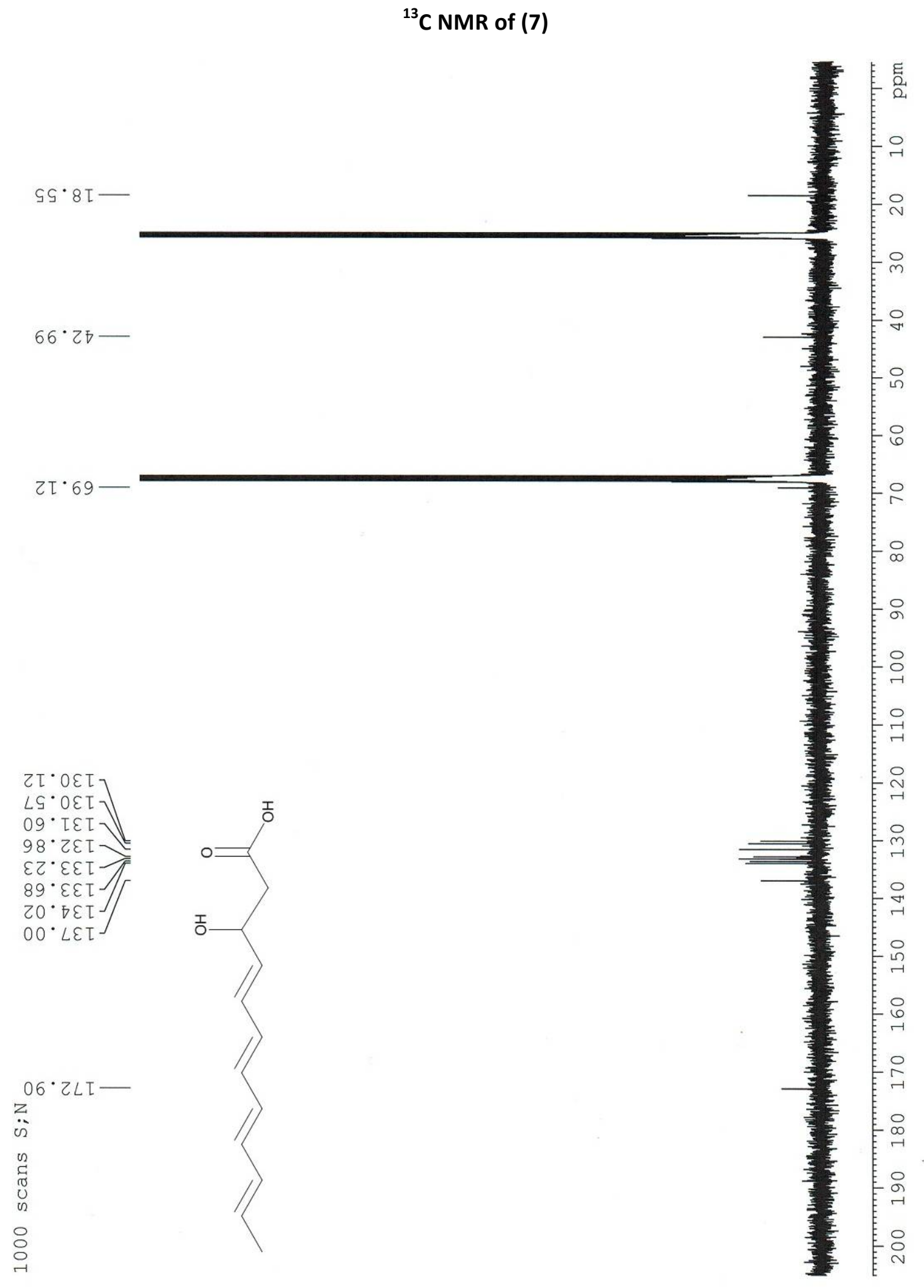


${ }^{1} \mathrm{H}$ NMR of (8)

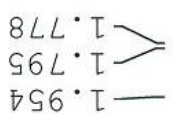

I6L 2 $66 L^{\circ} Z$ $208^{\circ} \mathrm{Z}$ $8 โ 8^{\circ} \mathrm{Z}$ $628^{\circ} \mathrm{r}$ $6 \varepsilon 0^{\circ} \varepsilon$ STF. $827 \cdot \varepsilon>$ 乙たゥ $\varepsilon$

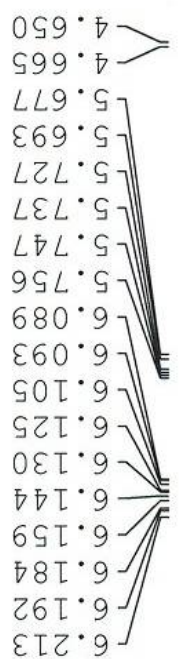

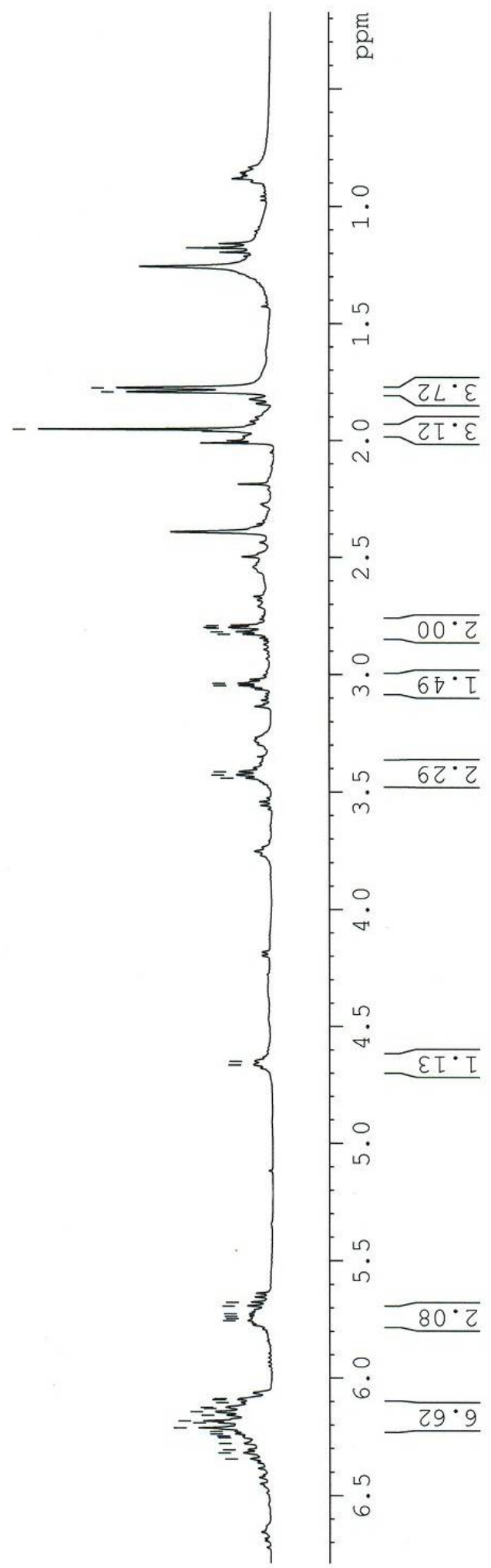


${ }^{13}$ C NMR of (8)
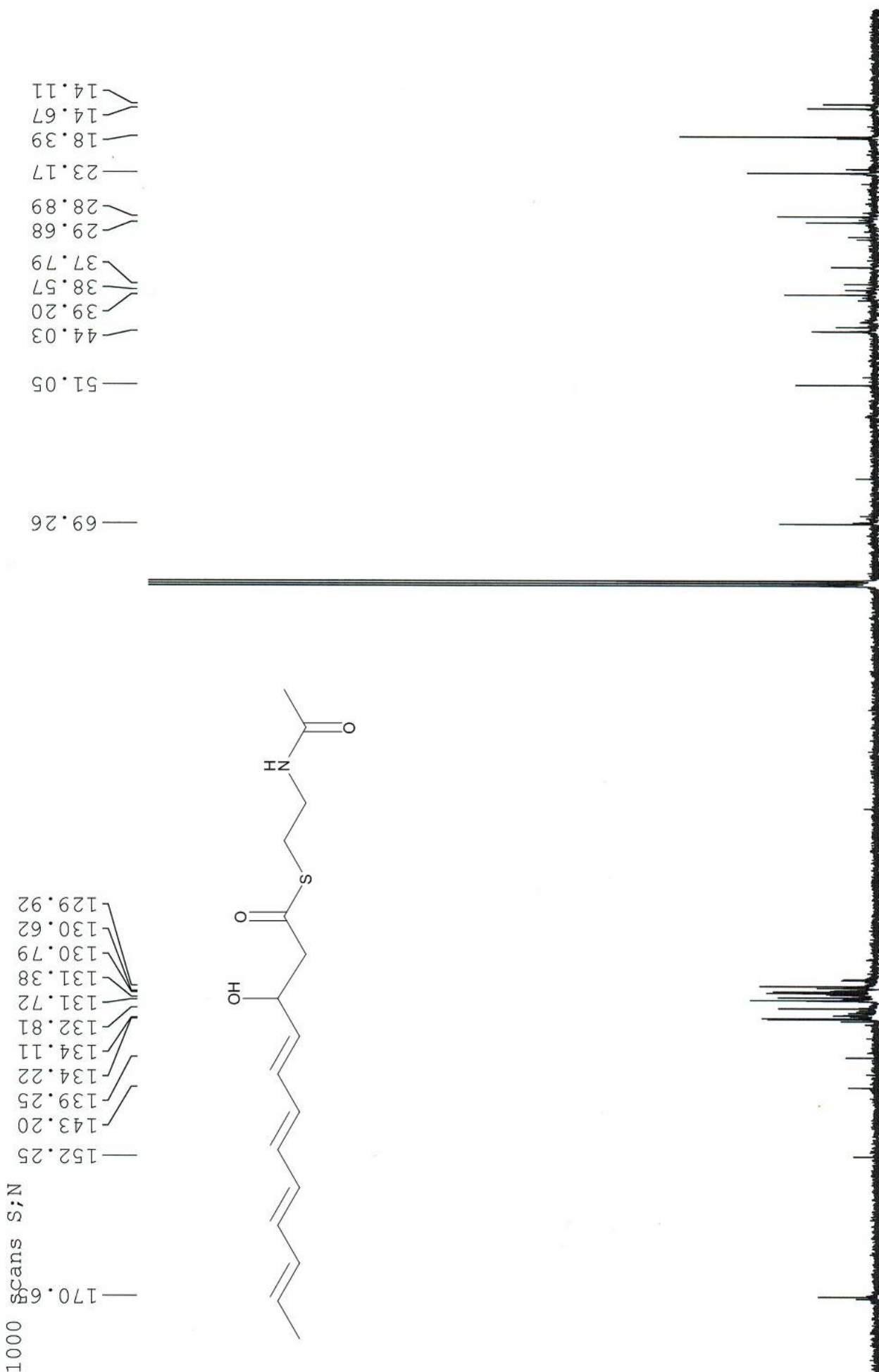


\section{${ }^{1}$ H NMR of (9)}
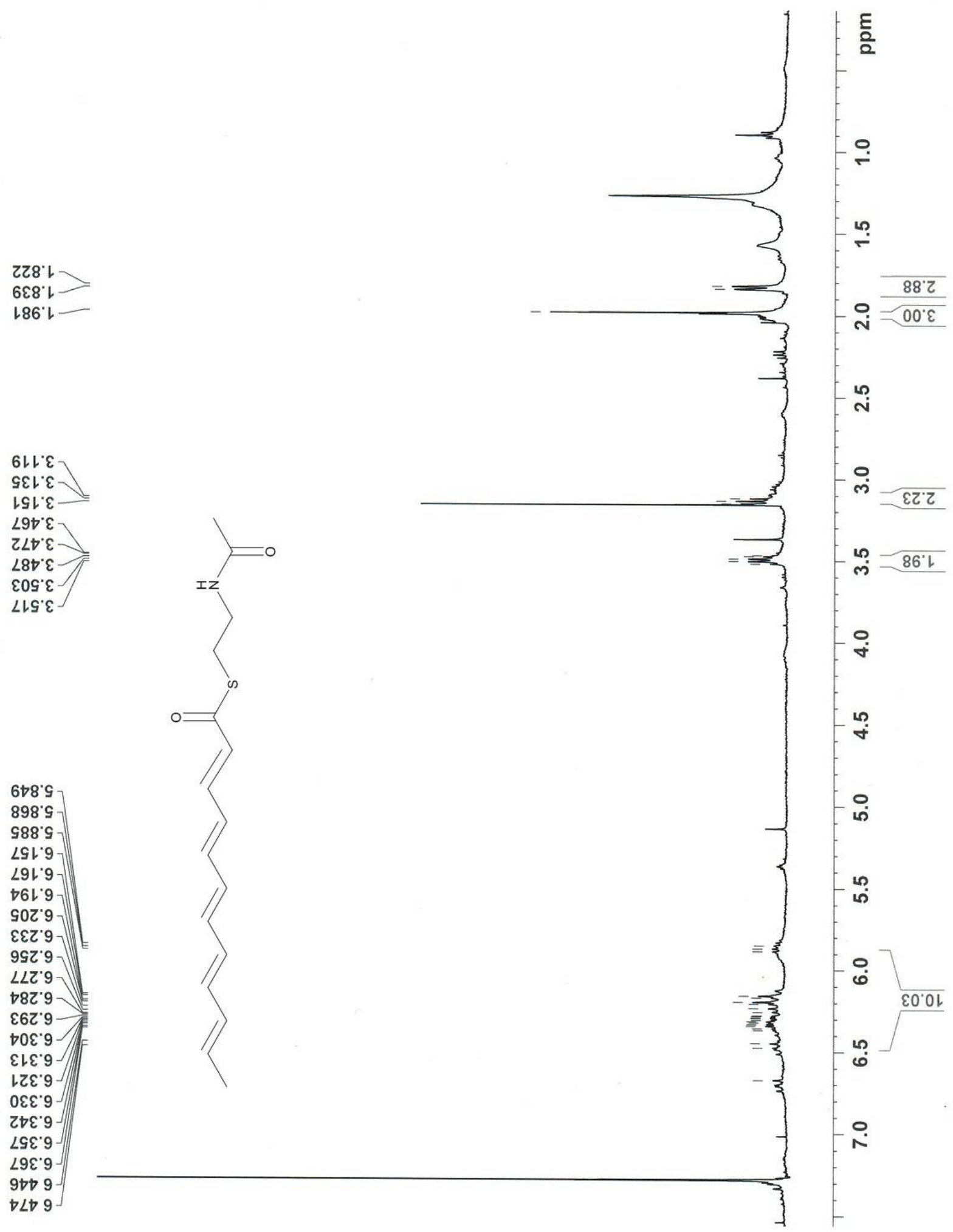
${ }^{13}$ C NMR of (9)
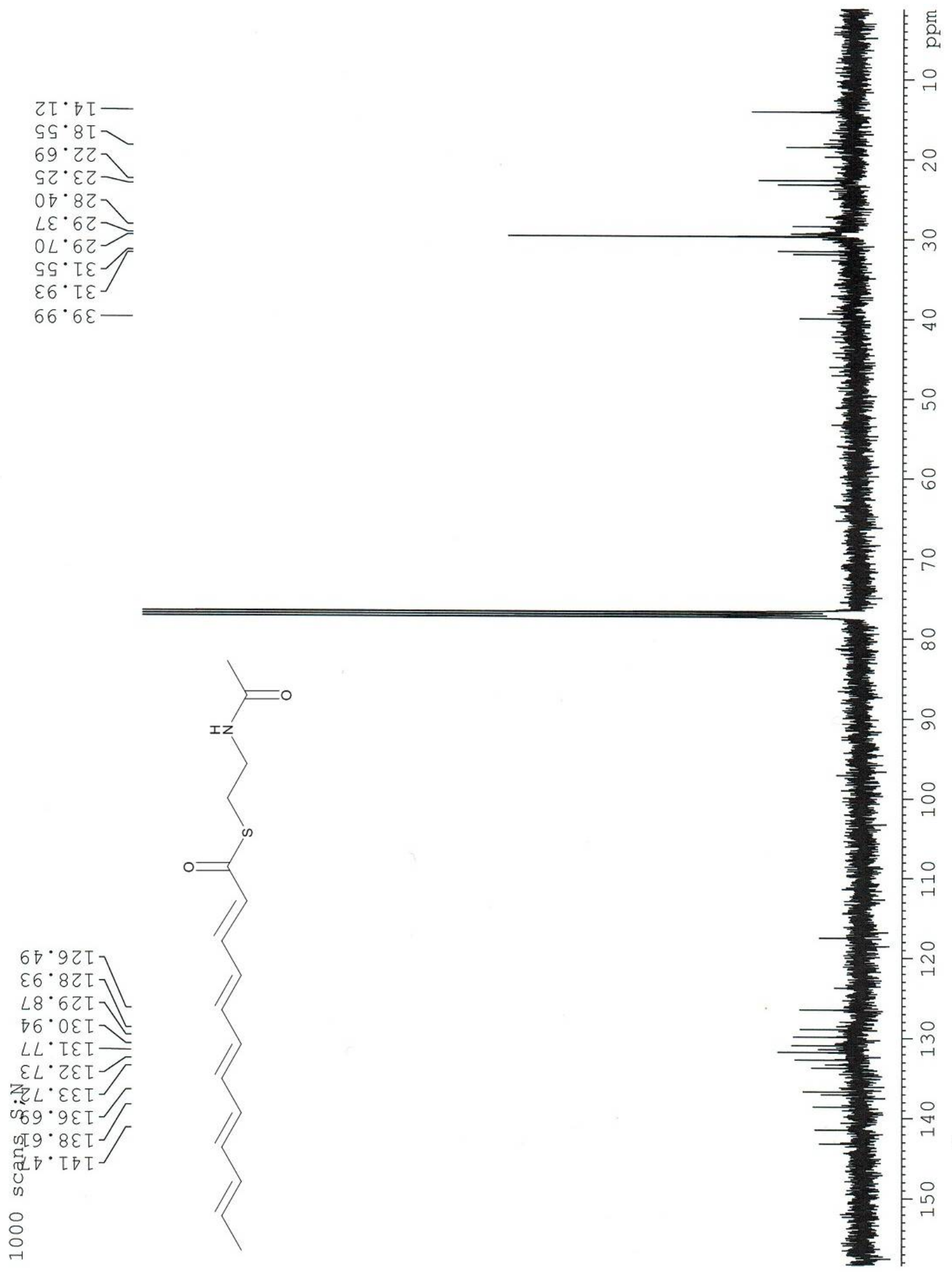